\title{
PENGARUH KINERJA KEUANGAN PERUSAHAAN TERHADAP PENGAMBILAN KEPUTUSAN INVESTOR DALAM SIKLUS HIDUP PERUSAHAAN YANG BERBEDA
}

\section{Laksmi Nitya Pradipta ${ }^{1)}$, Elizabeth Lucky Maretha Sitinjak ${ }^{2) 凶}$, Y. Wisnu Djati Sasmito $^{3}$}

Magister Manajemen, Magister Akuntansi, dan Manajemen FEB Unika Soegijapranata Semarang

\section{Info Artikel Abstrak}

Diserahkan Maret 2020

Diterima Maret 2020

Diterbitkan Maret 2020

Kata Kunci:

Financial Ratio, Company

Life Cycles, Individual

Investor Decisions
Pada penelitian ini akan memperlihatkan pengambilan keputusan investor pada setiap tahap siklus hidup memiliki pertimbangan rasio keuangan yang berbeda. Tujuan dari penelitian adalah mengetahui pengaruh kinerja keuangan perusahaan terhadap pengambilan keputusan investor pada lima tahap siklus hidup perusahaan yaitu introduction, growth, leverage, shakeout dan decline. Penelitian menggunakan data perusahaan manufaktur periode 2014-2016. Analisis dilakukan dengan alat analisis SPSS. Hasilnya rasio yang mempengaruhi pengambilan keputusan investor pada setiap siklusnya berbeda. Pada tahap introduction hanya rasio likuiditas yang berpengaruh pada pengambilan keputusan investor dengan arah positif. Tahap growth rasio leverage yang berpengaruh pada pengambilan keputusan investor dengan arah negatif dan rasio aktivitas dengan arah negatif. Tahap shakeout hanya rasio likuiditas yang berpengaruh pada pengambilan keputusan investor dengan arah positif. Tahap mature rasio profitabilitas yang berpengaruh pada pengambilan keputusan investor dengan arah positif, rasio likuiditas berpengaruh dengan arah negatif dan rasio leverage berpengaruh dengan arah positif. Tahap decline yang berpengaruh pada pengambilan keputusan investor adalah rasio leverage dengan arah negatih sedangkan rasio likuiditas dan aktivitas memiliki arah positif. 


\section{Pendahuluan}

Pengambilan keputusan menjadi hal yang memegang peranan penting dalam kehidupan sehari-hari. Salah satu pengambilan keputusan dilakukan oleh investor yang ingin melakukan investasi. Investasi diharapkan dapat membawa keuntungan di masa mendatang, inilah sebabnya perlu dilakukan analisis dan perhitungan mendalam dengan penuh kehati-hatian. Keputusan yang diambil investor bisa berupa membeli dan menjual saham yang akan terlihat dari frekuensi saham yang ada di BEI. Semakin tinggi frekuensi saham perusahaan bisa menunjukkan semakin berminatnya pemegang saham pada perusahaan tersebut. Ini sesuai dengan hasil dari Faries, Anastasia dan Memarista (2014) bahwa pengambilan keputusan investor tercermin dari frekuensi investor dalam melakukan trading. Hal ini juga didukung dari hasil penelitian Barber dan Odean (2011) yang menyatakan dengan frekuensi trading lebih baik dalam pengambilan keputusan investor karena dengan semakin tingginya trading berarti investor memiliki kecenderungan lebih dalam minat pembelian saham.

Investor atau pemegang saham saat ini cenderung bersikap rasional, dan perlu mempertimbangkan informasi secara jelas dalam mengambil keputusan investasi. Kinerja keuangan juga menjadi pertimbangan investor untuk melakukan keputusan investasinya Informasi mengenai kinerja perusahaan bisa didapatkan dari menganalisis laporan keuangan perusahaan. Dari sini dapat dilihat kemampuan perusahaan untuk menjalankan bisnisnya (Puspitaningtyas, 2013). Para pemegang saham akan lebih cenderung memilih perusahaan yang memiliki kinerja perusahaan yang baik dengan rasio-rasio keuangan yang menunjukkan kinerja perusahaan yang baik. Rasio yang biasa digunakan adalah empat rasio keuangan yaitu rasio profitabilitas, rasio leverage, rasio aktivitas, dan rasio likuiditas perusahaan Brealey, Myers \& Marcus (2015). Penggambaran keuangan perusahaan bisa didapatkan dengan rasio, dengan rasio ini akan bisa menganalisa tentang keefektifan kebijakan perusahaan pada periode tertentu (Palepu, Healy \& Peek, 2014) sehingga dapat diketahui baik buruknya kondisi perusahaan.

Rasio-rasio yang menggambarkan kondisi perusahaan akan dianalisa oleh investor. Jika laporan keuangan menggambarkan kondisi keuangan perusahaan yang tidak baik maka akan muncul kecenderungan investor tidak mau membeli saham dari perusahaan tersebut. Ini menjadi tantangan untuk perusahaan untuk tetap bertahan dalam persaingan bisnis saat ini agar tetap diminati investor, sehingga perusahaan perlu memiliki kemampuan beradaptasi. Perusahaan dapat melakukan adaptasi dengan menghubungkan informasi mengenai perkembangan perusahaan dan lingkungannya di masa lalu, masa kini dan masa depan. Informasi ini bisa berbeda pada setiap waktu dan pada tiap perusahaan karena tergantung masalah dan proses yang dihadapi perusahaan sehingga akan mempengaruhi siklus hidup yang akan dialami perusahaan. Siklus hidup perusahaan akan berbeda dari luas dan modelnya walaupun sebenarnya siklus hidup perusahaan hanya ada lima tahap yaitu introduction, growth, shake-out, mature, dan decline. Oleh karena itu penting untuk perusahaan dapat memahami siklus hidup perusahaan.

Siklus hidup perusahaan dapat dilihat dari berbagai aspek seperti umur perusahaan dan ukuran perusahaan, namun siklus hidup perusahaan yang dinilai dengan umur perusahaan dan ukuran perusahaan ini sangatlah tidak fleksibel dan kurang sesuai digunakan untuk menggambarkan keberagaman tiap-tiap perusahaan karena perusahaan dianggap akan melalui tahap dari introduction hingga decline secara berurutan dan mati. Dalam penelitian ini siklus hidup diklasifikasikan dari kombinasi arus kas operasi, arus kas investasi, dan arus kas pembiayaan. Tabel 1 memperlihatkan kombinasi arus kas dengan tanda minus (-) dan tanda plus $(+)$. Tanda (-) artinya perusahaan memiliki nilai defisit pada arus kas dan tanda (+) artinya perusahaan memiliki nilai surplus pada arus kasnya. Jika perusahaan memiliki arus kas operasi dan investasi defisit yang ditandai tanda (-) dan memiliki nilai surplus di arus kas pembiayaan yang ditandai dengan tanda $(+)$ 
artinya perusahaan tersebut ada di tahap siklus hidup introduction (Drobetz et al., 2015). Kombinasi tanda pada arus kas dapat dilihat lebih jelas di tabel 1 sebagai berikut:

Tabel 1.

Pembagian Tahap Siklus Hidup

\begin{tabular}{|l|c|c|c|c|c|}
\hline \multicolumn{1}{|c|}{ Arus Kas } & Introduction & Growth & Shakeout & Mature & Decline \\
\hline Arus Kas Operasi & - & + & +- & + & - \\
\hline Arus Kas Investasi & - & - & +- & - & + \\
\hline Arus Kas Pembiayaan & + & + & +- & - & $+/$ \\
\hline
\end{tabular}

Sumber: (Drobetz, Halling \& Schröder, 2015)

Bagi investor salah satu sektor saham yang cukup menarik untuk melakukan investasi adalah perusahaan manufaktur ini karena di Indonesia perusahaan manufaktur semakin lama semakin menunjukan pertumbuhan yang baik. Li Yong (2016) menyatakan Indonesia bahkan berhasil mendapat rangking ke-10 dunia dalam industri manufaktur

Maka dari uraian di atas, penelitian ini akan meneliti tentang benarkah para investor melihat sisi intern perusahaan dalam kasus ini laporan keuangan khususnya arus kas dan rasiorasio seperti rasio profitabilitas, rasio leverage, rasio aktivitas, dan rasio likuiditas. Oleh sebab itu penulis memutuskan penelitian ini berjudul "Pengaruh Kinerja Keuangan Perusahaan terhadap Pengambilan Keputusan Investor Pasar Saham dalam Siklus Hidup Perusahaan yang Berbeda".

\section{Metode Penelitian}

\subsection{Populasi dan Sampel}

Populasi dari penelitian ini adalah semua perusahaan manufaktur yang telah terdaftar di Bursa Efek Indonesia selama periode 2014-2016. Teknik sampling yang digunakan pada penelitian ini adalah purposive sampling dengan kriteria memiliki laporan keuangan yang tersaji per 31 Desember, dan data lengkap tersaji untuk penelitian yaitu memiliki laporan arus kas dan data-data untuk rasio.

Sampel penelitian ini selama 2014-2016 secara berturut-turut adalah 137, 136, dan 137. Sampel kemudian diklasifikasikan menurut siklus hidupnya yang terbagi menjadi 5 tahap yaitu introduction, growth, shake-out, mature dan decline. Jumlah perusahaan introduction 68 perusahaan, growth 117 perusahaan, shake-out
35 perusahaan, mature 175 perusahaan dan decline 15 perusahaan.

\subsection{Lokasi dan Objek Penelitian}

Lokasi dari penelitian ini adalah di Bursa Efek Indonesia (BEI) melalui web resminya yaitu www.idx.co.id. Objek penelitian dari penelitian ini adalah laporan keuangan perusahaan yang ada di sektor manufaktur pada periode 2014-2016

\subsection{Analisis Data}

Penelitian ini menggunakan analisis regresi linier berganda dengan bantuan alat SPSS. Analisis dilakukan pada data perusahaan yang sudah dikelompokkan terlebih dahulu sesuai siklus hidupnya. Pertama yang akan dilakukan adalah uji asumsi klasik dengan uji normalitas dengan Kolmogorov-Smirnov, penghapusan outlier untuk data yang belum normal, heteroskedastisitas dengan uji Glesjer dan multikolonieritas dengan nilai tolerance dan variance inflatoin factor, dan kemudian dilanjutkan analisis hasil regresi untuk mengetahui pengaruh rasio keuangan terhadap pengambilan keputusan investor. Berikut adalah model regresi dasar untuk kelima tahap siklus hidup:

$$
\mathrm{PKI}=\square 0+\mathrm{b} 1 \mathrm{RP}+\mathrm{b} 2 \mathrm{RLE}+\mathrm{b} 3 \mathrm{RLI}+\mathrm{b} 4 \mathrm{RA}+\mathrm{ei}
$$

\section{Keterangan:}

$$
\begin{aligned}
& \text { PKI1 }=\text { Pengambilan Keputusan Investor } \\
& \text { RP }=\text { Rasio Profitabilitas } \\
& \text { RLE }=\text { Rasio Leverage } \\
& \text { RLI }=\text { Rasio Likuiditas } \\
& \text { RA }=\text { Rasio Aktivitas } \\
& \text { b1, b2, } b 3, \text { dan b4 = koefisien pada tahap } \\
& \quad \text { introduction } \\
& \mathrm{e} \quad=\text { error }
\end{aligned}
$$

\section{Hasil dan Pembahasan}

Pada tahap introduction diketahui bahwa hanya rasio likuiditas yang berpengaruh terhadap pengambilan keputusan investor pada tahap introduction dengan nilai signifikansinya $<1 \%$, Artinya rasio likuiditas berpengaruh secara signifikan di tingkat $1 \%$. Hasil penelitian ini mendukung penelitian yang dilakukan Wira (2012), Ohoira (2012), Dewi, Wahyuni \& Purnamawati (2016) dimana rasio likuiditas berpengaruh positif signifikan kepada pengambilan keputusan investor (frekuensi 
perdagangan saham). Tahap Introduction adalah tahapan dimana biasanya perusahaan masih ditahap awal yang biasanya akan mengalami arus kas yang negatif dari aktivitas operasinya. Arus kas investasinya juga negatif karena dampak melakukan investasi besar untuk menyediakan atau memperbarui basis kegiatan operasinya. Arus kas pendanaan diharapkan positif karena biasanya perusahaan introduction sumber daya modal yang belum memadai. Pengaruh likuiditas adalah positif terhadap keputusan investor pada tahap introduction. Ini berarti perusahaan masih dianggap oleh investor baik dalam memenuhi kewajiban jangka pendeknya dengan aset lancarnya. Bagi perusahaan pada tahap introduction perlu melakukan peminjaman dari pihak ketiga namun yang beresiko rendah jika bisa lebih diarahkan pada peminjaman jangka panjang dan perlu pengembangan asetnya.

Tabel 2.

Hasil Penelitian Tahap Introduction

\begin{tabular}{|c|c|c|c|c|c|c|}
\hline Tahap & Hipotesis & Uji F & $\begin{array}{c}\text { Adjust. } \\
\mathrm{R}^{2} .\end{array}$ & Sig. & Arah & Keterangan \\
\hline \multirow{4}{*}{$\begin{array}{l}\begin{array}{l}\text { Introd } \\
\text { uction }\end{array} \\
\text { a }\end{array}$} & $\begin{array}{l}\text { H1a: Likuiditas berpengaruh positif } \\
\text { pada pengambilan keputusan } \\
\text { investor }\end{array}$ & \multirow{4}{*}{0.002} & \multirow{4}{*}{0,29} & 0,000 & Positif & $\begin{array}{l}\text { Signifikan } \\
\text { dan searah }\end{array}$ \\
\hline & $\begin{array}{l}\text { H1b: Aktivitas berpengaruh positif } \\
\text { pada pengambilan keputusan } \\
\text { investor }\end{array}$ & & & 0,392 & Negatif & $\begin{array}{c}\text { Tidak } \\
\text { signifikan }\end{array}$ \\
\hline & $\begin{array}{l}\text { H1c: Profitabilitas berpengaruh } \\
\text { positif pada pengambilan } \\
\text { keputusan investor }\end{array}$ & & & 0,575 & Negatif & $\begin{array}{c}\text { Tidak } \\
\text { signifikan }\end{array}$ \\
\hline & $\begin{array}{l}\text { H1d: Leverage berpengaruh negatif } \\
\text { pada pengambilan keputusan } \\
\text { investor }\end{array}$ & & & 0,191 & Positif & $\begin{array}{c}\text { Tidak } \\
\text { signifikan }\end{array}$ \\
\hline
\end{tabular}

Sumber: diolah

Pada tahap growth variabel leverage memiliki nilai signifikan $0,028<5 \%$ sehingga memiliki pengaruh pada pengambilan keputusan investor. Leverage berpengaruh signifikan kepada pengambilan keputusan investor di tingkat 5\% dengan arah negatif. Variabel aktivitas memiliki nilai signifikan $0,009<1 \%$ namun memiliki arah yang negatif sehingga tidak memenuhi syarat hipotesis. Variabel profitabilitas yang memiliki nilai 0,7 dan variabel likuiditas yang memiliki nilai 0,281 yang lebih besar dari 0,05 dinyatakan tidak berpengaruh pada pengambilan keputusan investor pada tahap growth. Rasio aktivitas memiliki pengaruh dengan signifikan $1 \%$, namun memiliki arah yang berbeda dari hipotesis yaitu rasio aktivitas yang seharusnya pengaruhnya positif malah memiliki pengaruh yang negatif terhadap pengambilan keputusan investor. TATO pada perusahaan manufaktur akan meningkat nilainya jika terjadi kenaikan penjualan dan inventory yang berkurang. Pengaruh negatif ini karena investor khawatir tentang persediaan perusahaan yang ditakutkan tidak mencukupi untuk memenuhi permintaan konsumen yang sedang meningkat terus di tahap growth. Pada tahap growth ini memang perusahaan bisa melakukan pinjaman pada pihak ketiga yang digunakan untuk investasi pada aset tetap untuk peningkatan operasional dan pengembangan perusahaan namun perlu diingat bahwa investor melihat sisi leverage perusahaan sehingga perlu diperhitungkan jumlah hutang yang perlu diambil.

Tabel 3. Hasil Penelitian Tahap Growth

\begin{tabular}{|c|c|c|c|c|c|c|}
\hline Tahap & Hipotesis & Uji F & $\begin{array}{c}\text { Adjust. } \\
\mathrm{R}^{2}\end{array}$ & Sig. & Arah & Keterangan \\
\hline \multirow{4}{*}{ Growth } & $\begin{array}{l}\text { H2a: Likuiditas berpengaruh } \\
\text { positif pada pengambilan } \\
\text { keputusan investor }\end{array}$ & \multirow{4}{*}{0,007} & \multirow{4}{*}{0,107} & 0.281 & Positif & $\begin{array}{c}\text { Tidak } \\
\text { signifikan }\end{array}$ \\
\hline & $\begin{array}{l}\text { H2b: Aktivitas berpengaruh positif } \\
\text { pada pengambilan keputusan } \\
\text { investor }\end{array}$ & & & 0,009 & Negatif & $\begin{array}{c}\text { Signifikan, } \\
\text { tidak searah } \\
\text { hipotesis }\end{array}$ \\
\hline & $\begin{array}{l}\text { H2c: Profitibilitas berpengaruh } \\
\text { positif pada pengambilan } \\
\text { keputusan investor }\end{array}$ & & & 0.700 & Positif & $\begin{array}{c}\text { Tidak } \\
\text { signifikan }\end{array}$ \\
\hline & $\begin{array}{l}\text { H2d: Leverage berpengaruh } \\
\text { negatif pada pengambilan } \\
\text { keputusan investor }\end{array}$ & & & 0,028 & Negatif & $\begin{array}{l}\text { Signifikan } \\
\text { dan searah }\end{array}$ \\
\hline
\end{tabular}

Sumber: diolah

Pada tahap shakeout hanya rasio likuiditas yang berpengaruh terhadap pengambilan keputusan investor pada tahap shake out dengan nilai signifikansinya $0,000<1 \%$. Likuiditas berpengaruh terhadap pengambilan keputusan investor pada tingkat $1 \%$ dengan arah positif, hasil penelitian ini mendukung penelitian yang dilakukan Wira (2012), Ohoira (2012), Dewi, Wahyuni \& Purnamawati (2016). Pengaruh rasio likuiditas terhadap pengambilan keputusan investor adalah positif, artinya jika likuiditas perusahaan tinggi maka investor akan lebih ingin membeli saham perusahaan tersebut. Ini berarti perusahaan masih dianggap oleh investor baik dalam memenuhi kewajiban jangka pendeknya dengan aset lancarnya. Perusahaan perlu menjaga likuiditas perusahaan untuk bisa menarik para investor.

Tabel 4.

Hasil Penelitian Tahap Shakeout

\begin{tabular}{|c|c|c|c|c|c|c|}
\hline Tahap & Hipotesis & Uji F & $\begin{array}{c}\text { Adjust. } \\
\mathrm{R}^{2}\end{array}$ & Sig. & Arah & Keterangan \\
\hline \multirow{4}{*}{$\begin{array}{c}\text { Shake- } \\
\text { out }\end{array}$} & $\begin{array}{l}\text { H3a: Likuiditas berpengaruh } \\
\text { positif pada pengambilan } \\
\text { keputusan investor }\end{array}$ & \multirow{4}{*}{0.007} & \multirow{4}{*}{0.334} & 0,000 & Positif & $\begin{array}{l}\text { Signifikan } \\
\text { dan searah }\end{array}$ \\
\hline & $\begin{array}{l}\text { H3b: Aktivitas berpengaruh positif } \\
\text { pada pengambilan keputusan } \\
\text { investor }\end{array}$ & & & 0.509 & Negatif & $\begin{array}{c}\text { Tidak } \\
\text { signifikan }\end{array}$ \\
\hline & $\begin{array}{l}\text { H3c: Profitabilitas berpengaruh } \\
\text { positif pada pengambilan } \\
\text { keputusan investor }\end{array}$ & & & 0.883 & Positif & $\begin{array}{c}\text { Tidak } \\
\text { signifikan }\end{array}$ \\
\hline & $\begin{array}{l}\text { H3d: Leverage berpengaruh } \\
\text { negatif pada pengambilan } \\
\text { keputusan investor }\end{array}$ & & & 0,400 & Negatif & $\begin{array}{c}\text { Tidak } \\
\text { signifikan }\end{array}$ \\
\hline
\end{tabular}

Sumber: diolah 
Hasil dari pengujian hipotesis pada tahap mature rasio profitabilitas yang berpengaruh kepada pengambilan keputusan investor dengan nilai signifikan $0,000<1 \%$. Hasil ini sesuai dengan hasil penelitian Subhi (2011), Niam \& Retnani (2014), Aprillianto, Wulandari \& Kurrohman (2014), Ohoira (2012) serta Gunawan \& Jati (2014). Rasio leverage tidak memenuhi syarat hipotesis karena arah rasio yang seharusnya negatif namun di penelitian ini arahnya positif, dan rasio likuiditas juga seharusnya memiliki arah positif terhadap pengambilan keputusan investor namun hasil penelitian ini memiliki arah negatif.

Tabel 5.

Hasil Penelitian Tahap Mature

\begin{tabular}{|c|c|c|c|c|c|c|}
\hline Tahap & Hipotesis & Uji F & $\begin{array}{l}\text { Adjust. } \\
\mathrm{R}^{2}\end{array}$ & Sig. & Arah & Keterangan \\
\hline \multirow{4}{*}{ Mature } & $\begin{array}{l}\text { H4a: Likuiditas berpengaruh } \\
\text { positif pada pengambilan } \\
\text { keputusan investor }\end{array}$ & 0.000 & 0,667 & 0,004 & Negatif & $\begin{array}{c}\text { Signifikan, } \\
\text { tidak searah } \\
\text { hipotesis }\end{array}$ \\
\hline & $\begin{array}{l}\text { H4b: Aktivitas berpengaruh positif } \\
\text { pada pengambilan keputusan } \\
\text { investor }\end{array}$ & & & 0,511 & Negatif & $\begin{array}{c}\text { Tidak } \\
\text { signifikan }\end{array}$ \\
\hline & $\begin{array}{l}\text { H4c: Profitabilitas berpengaruh } \\
\text { positif pada pengambilan } \\
\text { keputusan investor }\end{array}$ & & & 0,000 & Positif & $\begin{array}{l}\text { Signifikan } \\
\text { dan searah }\end{array}$ \\
\hline & $\begin{array}{l}\text { H4d: Leverage berpengaruh } \\
\text { negatif pada pengambilan } \\
\text { keputusan investor }\end{array}$ & & & 0,017 & Positif & $\begin{array}{c}\text { Signifikan, } \\
\text { tidak searah } \\
\text { hipotesis }\end{array}$ \\
\hline
\end{tabular}

Sumber: diolah

Pada mature Rasio profitabilitas yang dapat mempengaruhi pengambilan keputusan investor pada tahap mature karena perusahaan harus mendapatkan keuntungan yang cukup tinggi bahkan setinggi-tingginya maka sudah sewajarnya investor melihat bagaimana laba perusahaan. Rasio lain yang signifikan pada timgkat $5 \%$ adalah leverage dan likuiditas namun memiliki arah pengaruh yang berbeda dari hipotesis. Rasio leverage memiliki arah positif terhadap pengambilan keputusan investor karena investor akan bahwa hutang perusahaan digunakan untuk perluasan perusahaan. Likuiditas pada tahap mature memiliki arah yang negatif karena investor menganggap bahwa aset lancar yang tinggi dianggap bahwa perusahaan boros membeli aset. Strategi yang perlu dilakukan perusahaan adalah berfokus pada kebutuhan untuk mempertahankan posisi "cash cow" perusahaan selama mungkin. Deviden bisa dibayarkan untuk memberikan imbal hasil kepada pemegang saham, imbal hasil dividen diharapkan meningkat. Diharapkan harga saham seharusnya menjadi jauh lebih stabil.
Pada tahap decline, variabel yang berpengaruh pada pengambilan keputusan investor adalah rasio leverage yang ditandai dengan nilai signifikannya $0,036<0,05(5 \%)$, rasio likuiditas ditandai dari nilai signifikannya yang sebesar $0,010<0,01(1 \%)$ dan rasio aktivitas yang ditandai nilai signifikan 0,012<0,05 (5\%). Variabel profitabilitas tidak berpengaruh pada pengambilan keputusan investor. Leverage berpengaruh pada pengambilan keputusan investor ini sesuai dengan hasil penelitian Niam \& Retnani (2014), Aprillianto, Wulandari \& Kurrohman (2014), Wira (2012) serta Rozenbaum (2016). Likuiditas berpengaruh pada pengambilan keputusan investor ini sesuai dengan hasil penelitian Wira (2012) , Ohoira (2012), Dewi, Wahyuni \& Purnamawati (2016). Aktivitas berpengaruh pada pengambilan keputusan investor sesuai dengan Syaefudin, Morasa \& Alexander (2015), Subhi (2011) Putri (2011), serta Budiyono (2017).

Tabel 6.

Hasil Penelitian Tahap Decline

\begin{tabular}{|c|c|c|c|c|c|c|}
\hline Tahap & Hipotesis & Uji F & $\begin{array}{c}\text { Adjust. } \\
\mathrm{R}^{2}\end{array}$ & Sig. & Arah & Keterangan \\
\hline \multirow{4}{*}{$\begin{array}{c}\text { Declin } \\
\mathrm{e}\end{array}$} & $\begin{array}{c}\text { H5a: Likuiditas berpengaruh } \\
\text { positif pada pengambilan } \\
\text { keputusan investor }\end{array}$ & 0,000 & 0,543 & 0,010 & Positif & $\begin{array}{l}\text { Signifikan } \\
\text { dan searah }\end{array}$ \\
\hline & $\begin{array}{l}\text { H5b: Aktivitas berpengaruh positif } \\
\text { pada pengambilan keputusan } \\
\text { investor }\end{array}$ & & & 0,012 & Positif & $\begin{array}{l}\text { Signifikan } \\
\text { dan searah }\end{array}$ \\
\hline & $\begin{array}{l}\text { H5c: Profitabilitas berpengaruh } \\
\text { positif pada pengambilan } \\
\text { keputusan investor }\end{array}$ & & & 0,865 & Positif & $\begin{array}{c}\text { Tidak } \\
\text { signifikan }\end{array}$ \\
\hline & $\begin{array}{l}\text { H5d: Leverage berpengaruh } \\
\text { negatif pada pengambilan } \\
\text { keputusan investor }\end{array}$ & & & 0,036 & Negatif & \\
\hline
\end{tabular}

Sumber: diolah

Pada tahap decline likuiditas dilihat karena perusahaan masih dianggap oleh investor baik dalam memenuhi kewajiban jangka pendeknya dengan aset lancarnya. Pengaruh rasio leverage terhadap pengambilan keputusan investor adalah negatif, ini berarti jika rasio leverage perusahaan semakin besar maka investor akan semakin malas untuk membeli saham perusahaan tersebut. Pada tahap siklus hidup decline para investor menganggap bahwa perusahaan mampu menggunakan ebitda perusahaan untuk melakukan kegiatan operasionalnya. Pada tahap ini perusahaan perlu melakukan pemotongan biaya untuk mempertahankan arus kas, dan mengurangi pinjaman yang ada. Jika dimungkinkan perusahaan melakukan peningkatan perputaran sehingga bisa memperbaiki keadaan perusahaan dan kembali ke tahap siklus hidup sebelumnya. 


\section{Kesimpulan}

Berdasarkan hasil penelitian dan pembahasan pada penelitian ini dapat diambil simpulan, kinerja RSUD Tugurejo Semarang ditinjau dari perspektif keuangan, yang diukur menggunakan instrumen penelitian value for money yang meliputi, rasio ekonomi, rasio efisiensi dan rasio efektivitas menunjukkan bahwa masih besarnya pengeluaran untuk memperoleh pendapatan, sehingga kurang efisien, namun besarnya pengeluaran masih di bawah anggaran yang ditetapkan sehingga dapat diambil kesimpulan bahwa kinerja perspektif keuangan tergolong cukup baik.

Kinerja RSUD Tugurejo Semarang ditinjau dari perspektif pelanggan dengan indikator kepuasan pasien, profitabilitas pasien, retensi pasien pada tahun 2009 dan 2010 menunjukkan hasil yang baik, hal ini terlihat pada tingkat kepuasan pasien yang menunjukkan bahwa sebagian besar pasien merasa puas, dengan angka kepuasan mencapai $70 \%$, hal ini mengindikasikan bahwa pasien merasa puas terhadap pelayanan yang diberikan RSUD Tugurejo Semarang sehingga rumah sakit dapat mempertahankan hubungan dengan pasien dan dapat menarik pasien baru.

Kinerja RSUD Tugurejo Semarang ditinjau dari perspektif proses bisnis internal pada tahun 2009 dan 2010 dengan indikator proses operasi sudah cukup baik, walaupun pada kedua tahun tersebut tidak ada proses inovasi.

Kinerja RSUD Tugurejo Semarang ditinjau dari perspektif pembelajaran dan pertumbuhan dengan indikator tingkat produktivitas karyawan, tingkat retensi karyawan, dan kepuasan karyawan pada tahun 2009 dan 2010 sudah baik, hal ini dapat dilihat pada tingkat produktivitas karyawan yang mengalami peningkatan dan survey kepuasan karyawan yang menunjukkan nilai $68 \%$, sehingga tingkat retensi karyawan pada tiap tahun relatif kecil.

\section{Daftar Pustaka}

Aprillianto, B., Wulandari, N., \& Kurrohman, T. 2014. Perilaku Investor Saham Individual Dalam Pengambilan Keputusan Investasi: Studi Hermeneutika-Kritis (Individual Stock Investors Behaviour In Investment Decision Making). eJournal Ekonomi Bisnis dan Akuntansi, 1(1), 16-31.

Barber, B. M., \& Odean, T. 2011. The behavior of individual investors. Social Sciences Research Network, (1), 1-54.

Bender, R., \& Ward, K. 2009. Corporate Financial Strategy (3rd edition). Oxford: Elsevier Butterworth-Heinemann.

Brealey, R. A., Myers, S. C., \& Marcus, A. J. 2015. Fundamentals of Corporate Finance. Power (Edisi 8). New York: McGraw-Hill.

Budiyono. 2017. Effect of Profit Margin, Turn Over Total Assets, Price Earnings Ratio and Capital Structure to Profitability (Return on Equity) on Companies Listed in Indonesia Stock Exchange in 2013-2015, 5(4), 6339-6345.

Christanti, N., \& Mahastanti, L. A. 2011. Faktor-Faktor yang Dipertimbangkan Investor dalam Melakukan Investasi. Jurnal Manajemen Teori dan Terapan, 4(3), 37-51.

Dewi, N. A. M., Wahyuni, M. A., \& Purnamawati, I. G. A. 2016. Pengaruh Cash Holdings, Profitabilitas, Dividen Payout Ratio, Umur Perusahaan, Reputasi Auditor, Kepemilikan Manajerial, Dan Kepemilikan Institusional Terhadap Nilai Perusahaan (Studi Empiris Pada Perusahaan Manufaktur Yang Terdaftar Di Bursa Efek Indonesia.

Dickinson, V. 2011. Cash Flow Patterns as A Proxy For Firm Life Cycle. Accounting Review, 86(6), 1969-1994

Drobetz, W., Halling, M., \& Schröder, H. 2015. Corporate Life-Cycle Dynamics of Cash Holdings. Swedish House of Finance Research Paper No 15-07 Corporate, (March), 1-38.

Fahmi, I. 2014. Studi Kelayakan Bisnis dan Keputusan Investasi. (Murkhana, Ed.). Jakarta: Mitra Wacana Media.

Faries, P. D. I., Anastasia, N., \& Memarista, G. 2014. Pengaruh Pengamatan Informasi Terhadap Frekuensi Trading Online Saham. Finesta, 2(1), 20-25. F

Ghozali, I. 2016. Aplikasi Analisis Multivariete dengan Program IMB SPSS 23. Semarang: Badan Penerbit Universitas Diponegoro.

Gunawan, I. P. A., \& Jati, I. K. 2013. Pengaruh Rasio Keuangan Terhadap Return Saham Unggulan yang Terdaftar di Bursa Efek Indonesia. E-Jurnal Akuntansi, 2(1), 1-18. 
Hill, C. W. L., Jones, G. R., \& Schilling, M. A. 2015. Strategic Management (Edisi 11). Stamford: Cengage Learning.

Ikatan Akuntan indonesia. 2017. Standar Akuntansi Keuangan. Dewan Standar Akuntansi Keuangan Ikatan Akuntan Indonesia.

Lubis, A. N., Sadalia, I., Fachrudin, K. A., \& Meliza, J. 2013. Buku Perilaku Investor Keuangan. USU Press.

Muhammad, B. 2010. Relevansi Nilai Yang Dimiliki Laba dan Arus Kas Berdasarkan Siklus Hidup Pada Tahap Growth Perusahaan Food and Beverages Yang Terdaftar di Bursa Efek Indonesia, (3).

Muhardi, W. R. 2013. Analisis Laporan Keuangan, Proyeksi dan Valuasi Saham. Jakarta: Salemba Empat.

Niam, F., \& Retnani, E. D. 2014. Analisis Kinerja Keuangan Sebagai Salah Satu Dasar Pengambilan Keputusan Investasi, 3(3).

Palepu, K. G., Healy, P. M., \& Peek, E. 2014. Analisis dan Valuasi Bisnis Berbasis IFRS (Edisi 2). Jakarta: Salemba Empat.

Pangesti, D. A. 2012. Pengukuran Kinerja Dengan Pendekatan Balanced Scorecard Pada Rumah Sakit Umum Daerah Kebumen.

Prastowo, D., \& Juliaty, R. 2008. Analisis Laporan Keuagan (Kedua). Yogyakarta: UPP STIM YKPN.

Puspitaningtyas, Z. 2012. Relevansi Nilai Informasi Akuntansi Dan Manfaatnya Bagi Investor. Jurnal Ekonomi dan Keuangan, 16(110), 164-183.

Puspitaningtyas, Z. 2013. Perilaku Investor Dalam Pengambilan Keputusan Investasi Di Pasar Modal, (October).

Rozebaum, O. 2013. EBITDA and Managers' Investment and Leverage Choices.

Silviyani, N. L. N. T., Sujana, E., \& Adiputra, I. M. P. 2014. Pengaruh Likuiditas Perdagangan Saham dan Kapitalisasi Pasar terhadap Return Saham Perusahaan yang Berada pada Indeks LQ45 di Bursa Efek Indonesia Periode Tahun 2009-2013 (Studi Empiris Pada Perusahaan LQ45 di Bursa Efek Indonesia). S1 Ak Universitas Pendidikan Ganesha, 2 No.1(1).

Taslim, A., \& Wijayanto, A. 2016. Pengaruh Frekuensi Perdagangan Saham, Volume Perdagangan Saham, Kapitalisasi Pasar dan Jumlah Hari Perdagangan terhadap Return Saham. Management Analysis Journal, 5(1), 1-6.

Tempo. 2016. unindo-indonesia-masuk-10-besar-negaraindustri-manufaktur@www.bkpm.go.id.

Virlics, A. 2013. Investment Decision Making and Risk. Procedia Economics and Finance, 6(December 2013), 169-177. 